\title{
THE POWER OF STATE COURTS TO ENJOIN FEDERAL OFFICERS
}

\author{
RICHARD S. ARNOLD*
}

THe question whether state courts have power to enter injunctions restraining or directing the conduct of officials of the United States may initially appear very simple. Since federal law, if constitutionally valid, is always supreme over state law, it would seem that federal officials should be free of interference from state courts. State judges, moreover, have not always had so much respect for federal law - particularly the federal Constitution - as they should have. It might be dangerous to concede them the power to frustrate that law by willfully erroneous injunctions. And finally, it may appear fitting that the rights of federal officials be adjudicated solely by national tribunals free of local jealousies.

These considerations have produced a line of New York cases that deny the power of state courts to enjoin federal officers. In the most influential of these cases, Armand Schmoll, Inc. v. Federal Reserve Bank, ${ }^{1}$ plaintiff brought suit in a state court to compel the Federal Reserve Bank of New York to perform a duty allegedly required of it by Section 522 of the Tariff Act of $1930 .^{2}$ The Bank claimed that the state courts had no jurisdiction to control its discharge of duties imposed by federal law. Although the plaintiff had no other remedy, since the federal courts at that time had no original mandamus jurisdiction, ${ }^{3}$ the New York Court of Appeals dismissed the suit for want of jurisdiction. State courts, the court said, generally have jurisdiction to adjudicate claims of federal right, but to allow them to control the manner in which a federal official performs a federal statutory duty would ignore the division between state and federal governments. In Fox v. 34 Hillside Realty Corp., ${ }^{4}$ the Supreme Court of New York, applying the Armand doctrine, refused to adjudicate a tenant's claim that a maximum-rent order of the Federal Area Rent Control Director was invalid under the Housing and Rent Act of 1947.5 A federal district court had already refused to hear the case on the ground of lack of the jurisdictional amount. ${ }^{6}$ The state judge regretted this failure of justice, but was not moved to grant relief:

The plight of these plaintiffs deprived of a review of a determination of an administrative officer ... is a most unfortunate but not unprecedented result of what has become known as administrative law. ${ }^{7}$

* Member of the Arkansas and District of Columbia Bars.

1. 286 N.Y. 503, 37 N.E.2d 225 (1941), cert. denied, 315 U.S. 818 (1942), 55 HARv. L. REv. 674 (1942).

2. Ch. 497, 46 Stat. 739 (1930).

3. McIntire v. Wood, 11 U.S. (7 Cranch) 503, 504 (1813) (federal courts have no original mandamus jurisdiction).

4. 87 N.Y.S.2d 351 (Sup. Ct. 1949), aff'd mem., 276 App. Div. 994, 95 N.Y.S.2d 598 (1950).

5. 61 Stat. 193 (1947), 50 U.S.C. $\S \S 1881-1902$ (1958).

6. 79 F. Supp. 832 (S.D.N.Y. 1948).

7. 87 N.Y.S.2d at 353. 
In Wasservogel v. Meyerowitz ${ }^{8}$ the Court of Appeals of New York expanded the doctrine by refusing to decide a claim that a federal housing regulation was unconstitutional. The supremacy clause, it said, forbids state courts to pass on the validity of federal administrative action.

In spite of the apparent certitude of the New York courts, the decided cases on state court power to entertain proceedings against federal officers are far from harmonious. On the one hand, state court power to punish federal officers for crime and to enter judgments at law against them is clear; on the other, the precedents uniformly hold that state courts may not determine the legality of the detention of persons in federal custody on a writ of habeas corpus, nor may they control federal officers by the prerogative writ of mandamus. The injunction cases lie in between these two lines of precedent. In spite of the cogency of the arguments put forward by the New York courts and others, I submit that, at least in the injunction area, basic principles of federalism not only permit, but require, that state courts have jurisdiction over federal officials. This article will attempt to demonstrate that doctrine hostile to this jurisdiction is merely an over-reaction to particularly flagrant instances of state courts abusing their power by not applying federal law in good faith; that power to grant relief against federal officials is a normal incident of the general judicial power possessed by all courts, state and federal; and that in many cases there will be no remedy at all if state courts do not have this power. I also intend to show that Congress has given ample protection to federal officers against any abuses of state court jurisdiction over them.

\section{The Habeas Corpus and Mandamus Cases}

Most of the early cases that contain any discussion of state court power over federal officials arose out of an effort by state courts to grant habeas corpus for prisoners or other persons in the custody of federal officers. For about eighty years after the adoption of the Constitution the state courts consistently asserted this power, ${ }^{9}$ largely unchallenged by the federal courts. Although there was no general power in federal courts to release state prisoners on habeas, since Congress had never conferred such jurisdiction, state courts were courts of general jurisdiction, and the writ of habeas corpus was regarded as an ordinary and usual incident of the judicial power granted by

8. 300 N.Y. 125, 89 N.E.2d 712 (1949). Accord, Fieger v. Glen Oaks Village, Inc., 309 N.Y. 527, 132 N.E.2d 492 (1956) ; Hunter v. City of New York, 121 N.Y.S.2d 841 (Sup. Ct. 1953) (alternative holding); cf. Lynbrook Gardens, Inc. v. Ullmann, 291 N.Y. 472, 53 N.E.2d 353 (1943), cert. denied, 322 U.S. 742 (1944).

9. See Warren, Federal and State Court Interference, 43 Harv. L. Rev. 345, 353 (1930); Bishop, The Jurisdiction of State and Federal Courts Over Federal Officers, 9 Colum. L. REv. 397, 404 (1909). There were a few exceptions to this claim of power. See, e.g., Williamson's Case, $26 \mathrm{~Pa} .9$ (1855). Chancellor Kent at first denied its existence, In re Ferguson, 9 Johns. R. 239 (Sup. Ct. 1812), but later recanted under pressure of authority. 1 Kent, Comanentaries *400-01 (14th ed. 1896). The state cases, including several unreported decisions, are collected in In re Reynolds, 20 Fed. Cas. 592 (No. 11721) (N.D.N.Y. 1867). 
state constitutions. ${ }^{10}$ The power was exercised in some instances of grave concern to federal interests. In 1833, for example, there was an attempt on the life of President Jackson. A federal grand jury in the District of Columbia investigating the attempt subpoenaed one Pleasants, editor of the Richmond Whig, to appear and give evidence. Pleasants disobeyed and was attached for contempt. He brought habeas corpus in a Virginia state court and was released on the ground that the District of Columbia grand jury's subpoena could not run into Virginia. The court reasoned that it had an obligation to protect Virginia citizens from unlawful restraint.11

As the conflict over slavery intensified, however, state habeas power began to run into determined opposition. The federal courts were anxious to protect federally guaranteed slaveholders' rights created by the Fugitive Slave Acts of 1793 and $1850 .{ }^{12}$ Under the Act of 1793 when a master had seized a fugitive slave, he was entitled to take him back home so long as he obtained a certificate of ownership, granted after summary proceeding before a federal judge or a county, city, or town magistrate. Since the state magistrates had been refusing to take jurisdiction under the 1793 act and there were few federal judges, the slaveowner's remedy was expanded in the 1850 act by giving commissioners of the federal circuit courts power to issue the certificate and by making federal marshals available to guard the slaveowner and the runaway on their way back South. But the Act of 1850 did not succeed in removing state-created impediments to the federal constitutional right. State judges began entertaining habeas applications on behalf of alleged slaves, and soon fugitives were being released by state courts on a number of grounds, including the unconstitutionality of the Act of 1850 . Typically, when a federal marshal accompanying a slaveowner was jailed by the state for disobeying a state writ of habeas corpus, he would bring federal habeas, ${ }^{13}$ and the federal courts would then be called upon to decide whether the state courts had power to release persons from federal custody. The federal courts could have ordered the marshals' release on the narrow ground that the certificates issued by the federal commissioner, by virtue of section 6 of the Act of 1850, had the effect of preventing interference with the custody of the slave by any court, judge, or

10. General federal habeas jurisdiction over state prisoners was not conferred until the Act of Feb. 5, 1867, ch. 27, 14 Stat. 385. One federal judge, in holding against state court power over federal prisoners, referred to this reciprocal lack of federal habeas jurisdiction over state prisoners. In re Veremaitre, 28 Fed. Cas. 1147 (No. 16915) (S.D.N.Y. 1850). See also In re Keeler, 14 Fed. Cas. 173, 174 (No. 7637) (D. Ark. 1843) (dictum). Mr. Justice Story described the question as an open one on the precedents. United States v. Bainbridge, 24 Fed. Cas. 946, 952 (No. 14497) (C.C.D. Mass. 1816) (dictum).

11. See Ex parte Pleasants, 19 Fed. Cas. 864 (No. 11225) (C.C.D.C. 1833) (reprinting, at pp. 864-68, the state court opinion).

12. Act of Feb. 12, 1793, ch. 7, 1 Stat. 302; Act of Sept. 18, 1850, ch. 60, 9 Stat. 462. These statutes were passed pursuant to Art. IV, $\$ 2$ of the Constitution.

13. Under $\S 7$ of the Act of March 2,1833, ch. 57, 4 Stat. 634 (the Force Bill, passed to counteract South Carolina's purported nullification of the federal Tariff Act of 1832), federal courts could issue habeas to release from state custody persons confined for any act done in pursuance of federal law. 
magistrate. Instead, they held broadly under the Constitution that when in a state habeas proceeding it became known that the relator was in federal custody, the state court's "jurisdiction ceases, and all further proceedings in the case will be coram non judice."14

The Supreme Court had occasion to settle the matter in 1859, in Ableman v. Booth.15 In studied defiance of federal law and federal judicial authority the Supreme Court of Wisconsin had twice released on habeas a prisoner in federal custody on a charge of aiding a slave's escape from a federal marshal. Then, when a writ of error was served upon its clerk in order to obtain United States Supreme Court review of the second release, it directed the clerk to make no return to the writ. ${ }^{16}$ Such conduct was hardly calculated to establish in the Supreme Court an attitude friendly to state power. Speaking for a unanimous Court, Mr. Chief Justice Taney declared that the state courts lacked power to inquire into the custody of federal prisoners - even where, as in the case before him, it was claimed that that custody violated the federal Constitution. The opinion would have been forceful enough had it been limited to holding that the state court could not defeat appellate review by the Supreme Court by refusing to make return on a writ served on its clerk and that the state court had erred on the merits in holding the Fugitive Slave Laws unconstitutional. It went much beyond those points, however, and, in sweeping language denied any state court jurisdiction to inquire into the legality of federal custody. Once the state courts know that the relator is held by a federal officer under a claim of federal authority,

They then know that the prisoner is within the dominion and jurisdiction of another Government, and that neither the writ of habeas corpus, nor any other process issued under State authority, can pass over the line of division between the two sovereignties. ${ }^{17}$

14. Ex parte Sifford, 22 Fed. Cas. 105, 109 (No. 12848) (S.D. Ohio 1857). Accord, Ex parte Robinson, 20 Fed. Cas. 965 (No. 11934) (C.C.S.D. Ohio 1856); Ex parte Robinson, 20 Fed. Cas. 969 (No. 11935) (C.C.S.D. Ohio 1855) ; Charge to Grand Jury - Fugitive Slave Law, 30 Fed. Cas. 1007 (No. 18261) (C.C.S.D.N.Y. 1851) ; Norris v. Newton, 18 Fed. Cas. 322 (No. 10307) (C.C.D. Ind. 1850). Cf. Extradition of Fugitives from Justice, 6 OPS. ATT'Y GeN. 237 (1853) (state courts have no power, on habeas, to decide legality of custody by federal authorities for extradition to a foreign country). Norris v. Newton, supra, appears to go so far as to say that state courts have no power to proceed in a habeas case once a slaveowner asserts that he holds the slave under federal law, even though the slaveowner is unaccompanied by a federal marshal, and no federal officer is a party to the case.

15. 62 U.S. (21 How.) 506 (1859).

16. The Attorney General of the United States, on whose motion the writ had been issued, then moved the Supreme Court to allow him to file with that Court a certified copy of the record in the state courts, and thereupon to treat the cause as docketed just as though the clerk of the lower court had made a proper return to the writ. The Court at first declined to take this extraordinary step, United States v. Booth, 59 U.S. (18 How.) 476 (1856), but when Wisconsin's recalcitrance continued for another Term it granted the Attorney General's motion.

17. 62 U.S. (21 How.) at 523. 
One wonders where the Court found this absolute prohibition. Nothing in the Constitution takes away such state court jurisdiction. The federal statute conferring habeas corpus jurisdiction on the federal courts ${ }^{18}$ does not say that this jurisdiction is exclusive of state courts, and, as will more fully appear below, ${ }^{10}$ the normal presumption is that state court power is not affected in the absence of express exclusion. It has been suggested that the rule may be found in "a federal common law of state-federal relations, developed by the courts but subject to control by Congress." 20 Perhaps the answer is that Ableman $v$. Booth is merely a special case of the general rule of judicial comity that once one court has obtained possession of a res and has begun to make an adjudication with respect thereto, all other courts should decline to interfere. This is the explanation offered by Mr. Chief Justice Taft in Ponzi v. Fessenden. ${ }^{21} \mathrm{Un}$ fortunately, this reasoning does not explain even Ableman $v$. Booth itself (to say nothing of some of its later applications). The second release of the federal prisoner in Ableman came after he had been finally convicted in a federal district court - there being no criminal appeal at that time - so that there was no interference with the federal court's power to dispose fully of the case before it. On the other hand, if we can forget for the moment that res judicata is no bar to a habeas proceeding, the case may simply show the Supreme Court's justifiable reluctance to have final federal judgments thwarted.

Whatever the rationale for Ableman, the case has not been limited to prevention of state interference with federal custody of criminal defendants or convicts. Some pre-existing authority, it is true, suggested a distinction between persons held on federal judicial process and persons held merely under executive power. ${ }^{22}$ It was apparently thought that state inquiry into judicially authorized federal custody was less tolerable. Most of the state court habeas cases before Ableman were brought to test the validity of a holding by the executive, specifically of enlistment by minors in the federal armed forces. Some courts continued to assert power in such cases even after Ableman. ${ }^{23}$

18. Judiciary Act of 1789 , ch. $20, \S 14,1$ Stat. 81.

19. See text accompanying notes 75-86 infra.

20. Hart \& Wechsler, The Federal Courts and the Federal Systear 388 (1953). See Note, Limitations on State Judicial Interference with Federal Authorities, 51 Couvur. L. Rev. 84, 85 n.12 (1951).

21. 258 U.S. 254 (1922). The "res" principle of priority of jurisdiction, the Court said, applies to persons, "as is shown by the great judgment of Chief Justice Taney in Ableman v. Booth ...." 258 U.S. at 261.

For application of the res principle see, e.g., Freeman: v. Howe, 65 U.S. (24 How.) 450 (1860); Duncan v. Darst, 42 U.S. (1 How.) 301 (1843).

22. See Collier's Case - Jurisdiction of Federal and State Courts, 6 Ors. Arr'y. GEN. 103 (1853).

23. For cases before Ablemant, see, e.g., State v. Dimick, 12 N.H. 197 (1841) ; Commonwealth v. Fox, $7 \mathrm{~Pa} .336$ (1848). For cases after Ableman see, e.g., In re Reynolds, 20 Fed. Cas. 592 (No. 11721) (N.D.N.Y. 1867) and cases cited therein; McConologue's Case, 107 Mass. 154 (1871). But see, e.g., In re Neill, 17 Fed. Cas. 1296 (No. 10089) (S.D.N.Y. 1871) ; In re Farrand, 8 Fed. Cas. 1070 (No. 4678) (D. Ky. 1867). 
But in 1871 the Supreme Court resolved all doubt; it solemnly reaffirmed Ableman and gave it a broad and uncompromising reading. ${ }^{24}$

Once again the Supreme Court of Wisconsin provided the opportunity for a sweeping opinion. This time habeas was sought by a father on behalf of his son, Edward Tarble. Edward's enlistment in the United States Army, the father alleged, was illegal, since the boy was under twenty-one. The father asked the state courts to order one Lieutenant Stone, who was in charge of Edward, to let the boy come home. The Wisconsin court did so, in the face of Ableman, which had been decided not much more than a decade before. The Supreme Court, in an opinion by Mr. Justice Field, reversed.25 The Court emphatically proclaimed that state courts were without jurisdiction to consider, on habeas corpus, the legality of any federal detention, be it judicial or executive. Copious extracts were reproduced from Ableman v. Booth, and that case was held to be a dispositive precedent. Not content with Ableman as a basis for the decision, Justice Field embarked on a lengthy dogmatic disquisition on the principles of federalism. State courts must not be permitted, he said, to make conflicting judgments on the validity of federal action. He expressly declined to limit Ableman to cases in which the state court was clearly attempting to circumvent a strong line of Supreme Court authority. The federal and state governments are completely independent sovereignties - except to the extent that federal courts may be called upon to uphold the supremacy of federal over state law. State courts cannot interfere with the execution of federal law - even if that law is unconstitutional. Until some federal court has declared a federal law invalid, it cannot be called in question by a state court, at least in a habeas corpus proceeding.

This reasoning, of course, was sufficient to dispose of the case. But Justice Field went further. The federal government, he said, could never execute its constitutional powers to make war and raise armies if state courts were continually setting soldiers free. The fear was expressed that state courts might embarrass the Government willfully. Nor would appellate review by the Supreme Court be a sufficient remedy, since in the period pending the appeal the soldier might be discharged and the mischief done. Federal habeas could not be similarly troublesome, since Congress could remedy any such difficulty. No fear need be entertained, the Court concluded, that liberty would be in danger. The federal courts would be open to redress illegal federal restraint.

A number of intriguing questions are raised by Tarble's Case. What if federal habeas, for one reason or another, were not available ? $^{20}$ Mr. Justice

24. Tarble's Case, 80 U.S. (13 Wall.) 397 (1871).

25. The vote was seven to one. Mr. Chief Justice Chase dissented. He thought state courts clearly had the power claimed and even suggested that denial of the power might violate the prohibition, U.S. CoNsT. Art. I, $\S 9, \mathrm{cl} .2$, against suspension of the writ of habeas corpus. 80 U.S. (13 Wall.) at 412. Mr. Justice Nelson took no part. Id. at ix.

26. Federal habeas jurisdiction is the creature of Congress. Ex parte Bollman, 8 U.S. (4 Cranch) 75, 94 (1807). But cf. Eisentrager v. Forrestal, 174 F.2d 961 (D.C. Cir. 
Field's language indicates that the Constitution forbids state jurisdiction $e x$ proprio vigore. That being so, would an act of Congress expressly conferring such power on state courts be unconstitutional ${ }^{27}$ Does the case really rest on a lack of subject-matter jurisdiction in the state courts, or is not its true basis some sort of federal privilege not to be sued in a "foreign" forum? Ponzi v. Fessenden ${ }^{28}$ is strong evidence that there is no want of subject-matter jurisdiction in the strict sense. There, the Court allowed a state court, with the consent of the Attorney General of the United States, to cause a federal prisoner to be produced before it on a writ of habeas corpus ad prosequendum for trial on a state criminal charge. In spite of these questions, however, there is no reason to believe that Tarble's Case would not be followed today, should a state court attempt to review the validity of a federal detention. Though there may be room for argument as to what constitutes custody "under the authority, or claim and color of the authority, of the United States," as opposed to custody "under the mere pretense of having such authority,"29 the basic principle seems secure. ${ }^{30}$

The cases in the mandamus area are just as emphatic in denying state court power. They stem from the early case of McClung $v$. Silliman. ${ }^{\mathbf{3 1}}$ There, suit was brought in the Circuit Court of the United States for the District of Ohio for a writ of mandamus to compel the registrar of a federal land office to issue a deed to the plaintiff. The registrar replied that the land had already been conveyed to another, and that accordingly he had no power to issue the deed demanded. The circuit court held that it had no jurisdiction, and the Supreme Court affirmed on the ground that Congress had not conferred mandamus jurisdiction on the federal courts, except in aid of some other portion of their powers. An original suit for mandamus, as opposed to an ancillary motion for the writ, could not be entertained. ${ }^{32}$

1949), rev'd on other grounds sub nom. Johnson v. Eisentrager, 339 U.S. 763 (1950); Fay v. Noia, 372 U.S. 391, 405-06 (1963) (dictum).

27. It may be that $\S 14$ of the Act of May 28, 1798, ch. 47, 1 Stat. 560, authorizing any federal judge or "any court or judge of a state, who, by the laws of such state, are authorized to issue writs of habeas corpus," to discharge any U.S. Army private arrested for debt, on application of his commanding officer, did in fact confer such power. This statute was repealed by $\$ \S 23 \& 29$ of the Act of March 16, 1802, ch. 9, 2 Stat. 136, and I find no record of its ever being invoked. Cf. 18 U.S.C. $\$ 3188$ (1958) (state judge may release fugitive not extradited within a fixed time).

28. 258 U.S. 254 (1922).

29. 80 U.S. (13 Wall.) 397, 410. Cf. Robb v. Connolly, 111 U.S. 624 (1884) (state habeas lies against officer of foreign state having custody of relator under federal interstate extradition statutes) (In re Robb, 19 Fed. 26 (C.C.D. Cal. 1884), contra, overruled); Application of House, 352 P.2d 131 (Alaska 1960) (state habeas lies at suit of federally convicted prisoner whose case, by virtue of the Alaska Statehood Act, 72 Stat. 349 (1958), has been transferred to state jurisdiction, even though relator is still held by federal authorities).

30. See, e.g., Ex parte Royall, 117 U.S. 241, 249-50 (1886).

31. 19 U.S. (6 Wheat.) 598 (1821).

32. McIntire v. Wood, 11 U.S. (7 Cranch) 503, 504 (1813). 
Whatever the merits of this determination, it closed the federal courts to plaintiff. He took the natural step of repairing to the state courts. Those courts were willing enough to take jurisdiction, but they held for the defendant on the merits. The plaintiff again sought Supreme Court review. That Court affirmed the state courts' judgment, but expressly on the ground of lack of jurisdiction. The state's assertion of jurisdiction, Mr. Justice Johnson said, was "an instance of the growing pretensions of some of the state courts over the exercise of the powers of the general government."33 Congress might have delegated to the federal courts the power to control federal officers; that it did not, the Court thought, clearly meant that it desired no court to have that power. A federal officer "can only be controlled by the power that created him ...."34 The plaintiff should proceed against the defendant federal officer by an action at law for damages or for recovery of specific property - "the ordinary mode of obtaining justice" - instead of invoking "the extraordinary and unprecedented mode of ... mandamus."35

It is hard to define the rationale of the case with precision. Probably it turned on the fact that mandamus is an extraordinary prerogative writ, and that Congress had not given federal courts mandamus jurisdiction. In stating the case a few years later, the Court emphasized that "The United States have not thought proper to delegate that power [mandamus] to their own courts."30 And it was apparently commonly supposed that mandamus was a special remedy that ran only from one organ of government to another organ of the same government. It was once doubted, for example, whether the Supreme Court could enforce its judgments by mandamus to the highest court of a state, and McClung v. Silliman was cited in support of the doubt. ${ }^{37} \mathrm{McClung}$ has been deemed controlling, moreover, when state courts have been asked or have attempted to mandamus federal officers. ${ }^{38}$ Though one later Supreme Court opinion appears to ignore it completely, ${ }^{3 \theta}$ there is no good reason to predict that $M c C l u n g$ will not govern whenever a plaintiff makes the mistake of labeling his papers "mandamus."

33. 19 U.S. (6 Wheat.) 598.

34. Id. at 605 .

35. Ibid.

36. Kendall v. United States ex rel. Stokes, 37 U.S. (12 Pet.) 524, 617 (1838). This decision modified McIntire to the extent of allowing the Circuit Court for the District of Columbia to exercise original mandamus jurisdiction. That peculiar distinction obtained until October 5, 1962, when Congress finally gave federal District Courts generally original mandamus jurisdiction, 28 U.S.C. \& 1361 (Supp. IV, 1963), without expressly excluding the state courts. Quaere, whether one ground of $M c C l i n g$ has not thus been cut away.

37. In re Blake, 175 U.S. 114, 119 (1899). But see Deen v. Hickman; 358 U.S. 57 (1958) (per curiam) (assuming that Supreme Court judgments may be enforced by mandamus to a state court).

38. See Ex parte Shockley, 17 F.2d 133 (N.D. Ohio 1926); Fischer v. Daudistal, 9 Fed. 145 (C.C.E.D. Pa. 1881) (semble) ; Hinkle v. Town of Franklin, 118 W. Va. 585, 191 S.E. 291 (1937). But cf. Tuttle v. Iron Nat'1 Bank of Plattsburgh, 170 N.Y. 9, 62 N.E. 761 (1902) (per curiam).

39. Northern Pac. Ry. v. North Dakota ex rel. Langer, 250 U.S. 135, 151-52 (1919). 
It is thus clear, at least on the precedents, that state courts have no power to issue habeas corpus or mandamus to fedetal officials. The central issue for discussion, then, is whether McClung, Tarble's Case, or their principles prevent state courts from using their general equity powers in suits against federal agents or agencies.

\section{The Injunction Cases}

Authorities directly relevant to the issue of state court power to enjoin federal officers are not numerous. After Armand Schmoll, ${ }^{40}$ perhaps the most prominent is Pennsylvania Turnpike Comm'n v. McGinnes. ${ }^{41}$ The plaintiff state Turnpike Commission claimed that one of the defendants, Manu-Mine Research \& Development Co., had defrauded it of about one million dollars. It was further alleged that the fraudulently obtained funds had been paid as federal taxes to the defendant McGinnes, District Director of Internal Revenue, and that McGinnes was about to refund the money to Manu-Mine as an overpayment of taxes. If the money were thus refunded, plaintiff claimed, Manu-Mine would dissipate it before the Turnpike Commission could reach it. The complaint asked that McGinnes be forbidden to pay the money to Manu-Mine or its assignee, Seaboard Surety Co., and that he be directed to pay it over to the Turnpike Commission. Suit was first brought in a federal court, but it was dismissed for want of original jurisdiction. ${ }^{42}$ The plaintiff then went into the state court for the same relief. McGinnes removed the case to the federal district court on the ground that he was being sued for an act arising out of his official duties as an agent of the United States. ${ }^{43} \mathrm{He}$ then moved to dismiss for want of jurisdiction, and invoked the settled rule that a federal court can acquire no jurisdiction on removal if the state court had none to begin with. ${ }^{44}$ The motion was granted, and plaintiff was left without his remedy. The curious result of the decision was that a rule guarding federal officers from suit in state courts was applied to give them absolute protection from federal court suit as well.45

40. See notes 1-3 supra and accompanying text.

41. 179 F. Supp. 578 (E.D. Pa.), aff'd per curiam, 278 F.2d 330 (3d Cir. 1959), cert. denied, 364 U.S. 820 (1960).

42. Pennsylvania Turnpike Comm'n v. McGinnes, 268 F.2d 65 (3d Cir.), reversing 169 F. Supp. 580 (E.D. Pa. 1958), cert. denied, 361 U.S. 829 (1959). The case did not "arise under" federal law within the meaning of 28 U.S.C. \$ 1331 (1958), and reliance on the provision of 28 U.S.C. $\$ 2463$ (1958), that "all property taken or detained under any revenue law of the United States shall not be repleviable, but shall be deemed to be in the custody of the law and subject only to the orders and decrees of the courts of the United States having jurisdiction thereof," was unsuccessful because the suit did not concern any defined res.

43. 28 U.S.C. § 1442 (a) (1) (1958).

44. See, e.g., Lambert Run Coal Co. v. Baltimore \& O.R.R., 258 U.S. 377, 382 (1922).

45. Indeed, it may well be that the comprehensive federal officer removal provisions, 28 U.S.C. $\$ \S 1442$, 1442a (1958), which cover any "civil action or criminal prosecution commenced in a State court," represent a congressional assumption that state courts have jurisdiction of all ordinary civil proceedings against federal officers. On the other hand, it is only since 1948 that removal has been available to all federal officials - a fact that may explain pre-1948 reluctance to recognize state court power to enjoin federal officers. 
As the district court in McGinnes properly observed, most cases in point oppose state court injunction jurisdiction. ${ }^{46}$ Given $M c C l u n g$ and Ammand $S c h m o l l$, it is not surprising that the district judge in McGinnes was unwilling to innovate. There are precedents favoring the state courts' jurisdiction, however, ${ }^{47}$ and the Supreme Court has never decided the matter - although it might have done so had it not thought the question so difficult and of such "grave consequence." 48 Our inquiry need not be so diffident as that of the district court in $M c$ Ginnes.

First, it is important to bear in mind that there has never been any general rule against state court jurisdiction over federal officers. Those officers are subject in general to state law, just as every other person within the state's borders. The cases in which federal officials have been sued for damages in state courts are legion ; ${ }^{49}$ the jurisdiction does not even appear to have been questioned since 1852, when the Supreme Court unanimously upheld it in Teal v. Felton. ${ }^{50}$ That was an action of trover in a New York justice court against the postmaster of Syracuse, N.Y., claiming damages of six cents for wrongful refusal to deliver a newspaper to the plaintiff. Judgment went for the plaintiff in the state courts. On writ of error, counsel for the postmaster argued that such state court jurisdiction "would enable courts to adjudicate where the legislative authority could not act."51 McClung v. Silliman was relied on as an authority against the state courts' power, but the Supreme Court did not even bother to cite McClung in upholding the state courts.

Nor has state court power been limited to the special area of damages an area that might be distinguished as involving no direct interference with or obstruction of federal functions. State courts also have authority over actions at law for specific relief, such as replevin and ejectment 52 actions in

46. See, e.g., in addition to the cases discussed in the text, Keely v. Sanders, 99 U.S. 441 (1879) (dictum); Shanks Village Comm. v. Cary, 197 F.2d 212, 217-18 (2d Cir. 1952) (dictum) ; In re Turner, 119 Fed. 231 (C.C.S.D. Iowa 1902) ; Parry v. Delaney, 310 Mass. 107, 37 N.E.2d 249 (1941) (alternative holding); State Board of Health v. Wilson, 188 S.W.2d 999 (Tex. Civ. App. 1945).

47. See McNally v. Jackson, 7 F.2d 373 (E.D. La. 1925) ; Lewis Publishing Co. v. Wyman, 152 Fed. 200 (C.C.E.D. Mo. 1907) ; cf. Mallory v. Wheeler, 151 Wis. 136, 138 N.W. 97 (1912).

48. Brooks v. Dewar, 313 U.S. 354, 360 (1941). See also Wheeldin v. Wheeler, 373 U.S. 647, 664 n.13 (1963) (dissenting opinion of Brennan, J.), treating the question as "unsettled."

49. See, e.g., Leroux v. Hudson, 109 U.S. 468 (1883) ; Sharp v. Doyle, 102 U.S. 686, 690 (1881); Buck v. Colbath, 70 U.S. (3 Wall.) 334 (1866); Benchley v. Gilbert, 3 Fed. Cas. 158 (No. 1291) (C.C.N.D.N.Y. 1871) ; Ex parte Jenkins, 13 Fed. Cas. 445, 448-50 (No. 7259) (C.C.E.D. Pa. 1853) ; Williams v. McDaniel, 80 Ga. App. 614, 56 S.E.2d 926 (1949). See 4 Ops. ATT'y GeN. 300 (1843). But cf. In re Gilbert, 276 U.S. 6, after hearing, 276 U.S. 294 (1928) (original disbarment proceeding).

50. 53 U.S. (12 How.) 284 (1852).

51. Id. at 287.

52. E.g., Stanley v. Schwalby, 147 U.S. 508 (1893), after remand, 162 U.S. 255 (1896) (assuming state court power over actions of ejectment) ; Carr v. United States, 98 U.S. 433 (1879). A number of removed cases also assume the jurisdiction. See, e.g., 
which the judgment may differ only in form from an injunction. Since Slocum v. Mayberry, ${ }^{53}$ which sustained state court power to entertain an action of replevin against a federal surveyor of customs, this jurisdiction at law has been unquestioned. ${ }^{54}$ Furthermore, state court criminal jurisdiction over federal officers has always been conceded, subject, of course, to the statutory power of federal courts to intervene by habeas corpus in cases of particular urgency. ${ }^{\text {to }}$

The cases rejecting state court injunction jurisdiction on constitutional grounds, moreover, are difficult, if not impossible, to square with another line of cases involving state court jurisdiction over national banks and other federal corporations and instrumentalities. The leading case in this category is First Nat'l Bank v. Missouri ex rel. Barrett. ${ }^{56}$ The Attorney General of Missouri brought an original proceeding in the supreme court of that state to test the authority of the respondent national bank to establish a branch. Under state practice, the proceeding was labeled as an information in the nature of quo warranto. The state court held for the Attorney General and directed the bank to close its branch on the grounds that state law prohibited branch banking, and that federal law did not authorize it. On error, the United States, appearing in support of the bank, urged that the state court was without jurisdiction to control the actions of a federal instrumentality. Ableman $v$. Booth and Tarble's Case were cited. ${ }^{57}$ The state pointed out that since Congress had not given federal courts jurisdiction of proceedings of this kind against national banks, the state courts must be open or the state's banking laws would be unenforceable. Only three Justices agreed that Tarble's Case barred the action." ${ }^{\text {ss }}$ The state government and courts, they thought, were totally distinct from the national government and courts, and without power to control them. Certainly the language of Tarble's Case supports this view. But the Court rejected it emphatically. True, national banks were federal instrumentalities. But they were subject to the general laws of the state - in-

Malone v. Bowdoin, 369 U.S. 643 (1962); Scranton v. Wheeler, 179 U.S. 141 (1900); Chappell v. Waterworth, 155 U.S. 102 (1894); United States v. Lee, 106 U.S. 196 (1882).

53. 15 U.S. (2 Wheat.) 1 (1817). The Attorney General of the United States, opposing the jurisdiction, cited, to no avail, In re Ferguson, 9 Johns. R. 239 (Sup. Ct. 1812), in which Chancellor Kent had denied state habeas jurisdiction over persons in federal custody. See note 1 sipra.

54. Except, that is, for the Government's attempt to claim, mainly on the basis of MFClung and a dictum in. Keely v. Sanders, 99 U.S. 441 (1879), that Sloctem "cannot be considered controlling at this date." Brief for Petitioner, p. 40 n.51, Brooks v. Dewar, 313 U.S. 354 (1941). It is worth noting that Slocum has been cited with approval as recently as Wheeldin v. Wheeler, 373 U.S. 647, 652 (1963). See also New Hampshire Fire Ins. Co. v. Scanlon, 362 U.S. 404, 408-09 (1960).

55. See, e.g., United States ext rel. Drury v. Lewis, 200 U.S. 1, 6 (1906). Compare Tennessee v. Davis, 100 U.S. 257 (1879).

56. 263 U.S. 640 (1924).

57. Id. at 646 (argument for the United States).

58. Id. at 667 (dissenting opinion). Mr. Justice Van Devanter wrote the dissenting opinion. He was joined by Taft, C.J., and Butler, J. 
cluding those prohibiting branch banking - so long as those laws did not contravene federal policy, as the Court held, and the dissenters assumed, they did not. That being so, the state statute must necessarily be enforceable in some forum, ${ }^{59}$ and since Congress had not conferred jurisdiction on federal courts, the courts of the state had to be that forum. ${ }^{60}$

In view of all this authority recognizing state court jurisdiction, it is hard to see why injunction cases have not been similarly treated. Indeed, in a large number of instances, injunction jurisdiction has been assumed not to be barred by the Constitution. ${ }^{61} \mathrm{Mr}$. Chief Justice Warren, for example, assumed it when he remarked that "The object of Section 7421(a) ${ }^{62}$ [of the Internal Revenue Code of 1954] is to withdraw jurisdiction from the state and federal courts to entertain suits seeking injunctions prohibiting the collection of federal taxes."63 Congress, moreover, has commonly assumed that federal corporations and agencies will be suable in state courts, once the bar of sovereign immunity - which, unlike the doctrine presently being examined, prevents suit in any court, state or federal - is removed by statute. Thus, it has provided that national banking associations "may make contracts, sue and be sued, complain and defend, in any court of law and equity as fully as natural

59. "To demonstrate the binding quality of a statute but deny the power of enforcement involves a fallacy made apparent by the mere statement of the proposition, for such power is essentially inherent in the very conception of law." Id. at 660 .

There is language on this page of the opinion which might indicate that the court regarded the state court as competent to enforce only state law: "It is insisted with great earnestness that the United States alone may inquire by quo warranto whether a national bank is acting in excess of its charter powers, and the state is wholly without authority to do so. This contention will be conceded since it is plainly correct. . . " It is submitted, however, that this language is prompted by the peculiar nature of quo warranto, which is a writ ruming from the sovereign to one of its corporations to find out under what authority the corporation is acting.

60. Accord, Guthrie v. Harkness, 199 U.S. 148 (1905); Texas ert rel. Falkner v. National Bank of Commerce, 290 F.2d 229 (5th Cir.), cert. denied, 368 U.S. 832 (1961) (on removal); Peoples Sav. Bank v. Stoddard, 359 Mich. 297, 102 N.W.2d 777 (1960). But see Millard จ. National Bank of Detroit, 338 Mich. 610, 61 N.W.2d 804 (1953) (holding that state courts may enforce state law, but not federal law, against national banks) ; Armand Schmoll, Inc. v. Federal Reserve Bank, 286 N.Y. 503, 37 N.E.2d 225 (1941), cert. denied, 315 U.S. 818 (1942).

61. See, e.g., Dakota Cent. Tel. Co. v. South Dakota ext rel. Payne, 250 U.S. 163 (1919); Macleod v. New England Tel. \& Tel. Co., 250 U.S. 195 (1919). The same assumption must underlie injunction cases removed from state courts; see, e.g., Dugan v. Rank, 373 U.S. 609 (1963); Tennessee Elec. Power Co. v. TVA, 306 U.S. 118 (1939); Snyder v. Marks, 109 U.S. 189 (1883) ; Bryant Bros. Co. v. Robinson, 149 Fed. 321 (5th Cir. 1906) ; Ward v. Congress Constr. Co., 99 Fed. 598 (7th Cir. 1900); Sarner v. Mason, 128 F. Supp. 165 (D.N.J. 1955), aff'd, 228 F.2d 176 (3d Cir. 1956), cert. denied, 351 U.S. 924 (1956) ; Underwood v. Dismuke, 266 Fed. 559 (D.R.I. 1920); City of Stanfield v. Umatilla R. Water Users Ass'n, 192 Fed. 596 (C.C.D. Ore. 1911); Twin Falls Canal Co. v. Foote, 192 Fed. 583 (C.C.D. Idaho 1911).

62. INT. REv. CODE of 1954, § 7421(a): "[N]o suit for the purpose of restraining the assessment or collection of any tax shall be maintained in any court."

63. Enochs v. Williams Packing \& Nav. Co., 370 U.S. 1, 5 (1962) (dictum). 
persons." 64 And it is clear that the phrase "any court" includes state courts. ${ }^{65}$ Congress has, also, expressly provided that national banking associations are not subject to "attachment, injunction, or execution . . . before final judgment in any suit, action, or proceeding, in any State, county, or municipal court."68 Such a protective provision obviously assumes that in its absence state courts could issue not only injunctions, but preliminary injunctions, against federal instrumentalities - an assumption wholly at war with the notion that the Constitution prohibits such state court jurisdiction. Any suggestion that this argument is limited to suits involving proprietary rather than governmental functions of federal agencies cannot stand in the face of $F H A v$. Burr. ${ }^{67}$ There, a statute authorizing the Federal Housing Administrator to "sue and be sued in any court of competent jurisdiction, State or Federal,"68 was construed to remove the bar of sovereign immunity as to all the normal incidents of litigation, legal and equitable, including, in that particular case, garnishment. ${ }^{69}$

In sum, then, the decided cases on state court power to entertain proceedings against federal officers are in confusion. Jurisdiction to award damages or possession of specific property, and to punish for crime, is clear. At the other extreme are mandamus and habeas corpus, which, whether for good reasons or not, state courts may not grant. In the middle is injunctive relief. Many cases assume its availability; some explicitly declare it; but most express rulings on the point deny it. ${ }^{70}$ Since no Supreme Court case squarely deals with the point, the matter cannot be resolved purely by reference to authority. An appeal must be made to first principles. Only by understanding the place of the state courts in the federal system can the question of those courts' power over federal officials be properly settled.

\section{The State Courts and the Federal System}

It is easy to fall into the assumption that because federal law is supreme over state law, state courts are somehow inferior to federal courts. This view would regard state courts as suitable for ordinary lawsuits, but would regard federal courts, specially constituted to hear issues of national importance, as the proper forum for cases arising under federal statutes or the Constitution. However tempting such a notion is, it is alien to the main stream of thought on federalism. Since the Constitution was signed, the state courts have been "the

64. REv. Stat. $\$ 5136$ (1875), 12 U.S.C. § 24 (1958) (emphasis supplied).

65. See Mercantile Nat'l Bank v. Langdeau, 371 U.S. 555 (1963).

66. Rev. Stat. § 5242 (1873), 12 U.S.C. § 91 (1958). Compare 48 Stat. 184, as amended, 12 U.S.C. $\$ 632$ (1958).

67. 309 U.S. 242 (1940).

68. 49 Stat. 722 (1935), 12 U.S.C. $\$ 1702$ (1958).

69. Cf. Federal Land Bank v. Priddy, 295 U.S. 229 (1935) (attachment).

70. In addition to the cases in this group already discussed, a few recent cases under Title III of the Civil Rights Act of 1960, 74 Stat. 86, 42 U.S.C. $\$ 1974$ (Supp. IV, 1963), deny the jurisdiction. These cases are dealt with at notes 101-08 infra and accompanying text. 
primary guarantors of constitutional rights."71 The federal courts are of limited, circumscribed jurisdiction. Only the Supreme Court of the United States has constitutional standing; all other federal courts are creatures of Congress, and Congress need never have created them. But the state courts are repositories of general jurisdiction, conferred upon them not by Congress, but by the sovereign people of the respective states.

These basic principles are well stated by Alexander Hamilton in Number LXXXII of The Federalist:

I mean not therefore to contend that the United States, in the course of legislation upon the objects intrusted to their direction, may not commit the decision of causes arising upon a particular regulation to the federal courts solely, if such a measure should be deemed expedient; but I hold that the State courts will be divested of no part of their primitive jurisdiction, further than may relate to an appeal; and I am even of opinion that in every case in which they were not expressly excluded by the future acts of the national legislature, they will of course take cognizance of the causes to which those acts may give birth. This I infer from the nature of judiciary power, and from the general genius of the system. The judiciary power of every government looks beyond its own local or municipal laws, and in civil cases lays hold of all subjects of litigation between parties within its jurisdiction, though the causes of dispute are relative to the laws of the most distant part of the globe. Those of Japan, not less than of New York, may furnish the objects of legal discussion to our courts. When in addition to this we consider the State governments and the national governments, as they truly are, in the light of kindred systems, and as parts of ONE WHOLE, the inference seems to be conclusive, that the State courts would have a concurrent jurisdiction in all cases arising under the laws of the Union, where it was not expressly prohibited. ${ }^{2}$

That the state courts' general jurisdiction extends, in the usual case, to cases arising under federal law, including the federal Constitution, is even more obvious when it is recalled that otherwise there would be no court competent to decide a large and important class of cases. Before 1875, as is well known, federal courts had no original jurisdiction over cases arising under the federal laws or Constitution. Such cases got into federal trial courts, by and large, only if the parties happened to be of diverse citizenship. Even now, when federal courts do have original "federal-question" jurisdiction, ${ }^{33}$ the state courts are still essential to decide cases arising under federal law that do not involve the $\$ 10,000$ jurisdictional amount required by Congress, to say nothing of cases arising under state law in which a federal law defense is asserted.

71. Hart \& Wechsler, The Federal Courts and the Federal System 339 (1953).

72. 2 The Federalist 130, 132 (Bourne ed. 1901). This passage is a locus classicus of federalism. The Supreme Court has repeatedly approved it. See Charles Dowd Box Co. v. Courtney, 368 U.S. 502, 508 n.5 (1962) ; Claflin v. Houseman, 93 U.S. 130, 138 (1877) ; Houston v. Moore, 18 U.S. (5 Wheat.) 1, 25-26 (1820).

73. 18 Stat. 470 (1875), 28 U.S.C. $\$ 1331$ (1958). 
The very statute ${ }^{74}$ that gives the Supreme Court appellate jurisdiction over state courts assumes in terms that state courts have power to decide federal questions, including questions of the constitutionality of federal statutes, for it expressly provides a different mode of review (appeal instead of certiorari) for state court decisions invalidating federal laws.

Not only are state courts the only courts competent to try many federal law cases, but also, as Hamilton pointed out, state court power in such cases is not negated ipso facto when Congress decides to delegate jurisdiction over them to federal courts of first instance. If the question of whether Congress, in conferring that jurisdiction upon its own courts, has taken away any of the state courts' pre-existing general judicial power was not irrevocably settled by Hamilton, the answer has been clear since the striking case of Houston $v$. Moore. ${ }^{75}$ Houston, a member of the Pennsylvania militia, had been summoned to federal service by order of the President. He disobeyed the summons and did not appear to serve, thus violating federal law and subjecting himself to a money penalty prescribed by federal law. He was tried and convicted of this offense by a state court-martial. His property was levied on and sold, and the fine thus collected was paid into the Treasury of the United States. Houston then brought trespass against the marshal who had seized and sold his property. He argued that only a federal court could try him for a federal military crime, and presented a very strong case for holding against state court jurisdiction. Not only did the case involve the military, an area of special federal concern, but the state court had also run directly counter to the maxim that the courts of one sovereign cannot enforce the criminal laws of another. ${ }^{76}$

In spite of these weighty considerations, the Supreme Court, in a strong opinion, upheld the jurisdiction of the state court-martial. The Court first disposed of the argument that since a state legislature may not make laws regulating the conduct of federal soldiers, state courts may not enforce such laws. That contention, the Court showed, was based on the notion that whenever a court of, say, Pennsylvania, made a decision, it must be applying the laws of Pennsylvania. Hamilton ${ }^{77}$ had already exploded that fallacy, and the Supreme Court now proceeded to do so too:

Admit, that the legislature of Pennsylvania could not constitutionally legislate in respect to delinquent militia-men, and prescribe the punishment to which they should be subject, had the state court-martial jurisdiction over the subject, so as to enforce the laws of Congress against these delinquents? This, it will be seen, is a different question from that 73).

74. 28 U.S.C. $\$ 1257$ (1958) (derived from $\$ 25$ of the Judiciary Act of 1789, 1 Stat.

75. 18 U.S. (5 Wheat.) 1 (1820).

76. If this maxim ever had any force in the federal system, it did not survive Tennessee v. Davis, 100 U.S. 257 (1880) (federal court may try state criminal charge against federal official on removal). Cf. Testa v. Katt, 330 U.S. 386 (1947) (state courts not only may, but must, enforce federal civil-penalty statute); see also Note, State Enforcement of Fcderally Created Rights, 73 HARv. L. Rev. 1551 (1960).

77. The Federalist No. 82 was approved and relied on by the Court. 18 U.S. (5 Wheat.) at 25-26. 
which has been just examined. That respects the power of a state legislature to legislate upon a subject, on which Congress has declared its will. This concerns the jurisdiction of a state military tribunal to adjudicate in a case which depends on a law of Congress, and to enforce it.78

There being no inherent disability barring state-court enforcement of federal laws, the Court next held, relying on Hamilton, that Congress's delegation of jurisdiction to a federal court-martial had not ousted the state court of jurisdiction. This resolution, the Court concluded, was confirmed by the practice of Congress. For the first Judiciary Act ${ }^{78}$ carefully marked out certain classes of cases, including crimes, that should be exclusively within the jurisdiction of the lower federal courts, "showing that, in the opinion of that body [the First Congress], it was not sufficient to vest an exclusive jurisdiction, where it was deemed proper, merely by a grant of jurisdiction generally."so Since military crimes were not within the first Judiciary Act, and since the statute giving to federal courts-martial cognizance of such crimes said nothing about exclusivity, it followed that the Pennsylvania court-martial had jurisdiction. ${ }^{81}$

This decision was no mere aberration. True, it was not unanimous: Mr. Justice Story, joined by another, unnamed Justice, dissented. ${ }^{82} \mathrm{He}$ thought Article III of the Constitution compelled Congress to delegate all the classes of cases therein named to some federal court, and forbade, ex proprio vigore, state court jurisdiction of certain types of federal law cases, including crimes - propositions that have not stood the test of time. Mr. Justice Johnson concurred separately, after admitting that "It is not very easy to form a distinct idea of what the question in this case really is." ${ }^{33}$ And Mr. Justice Washington, who wrote the majority opinion, noted that not all of the other three Justices "concur in all respects in the reasons which influence my opinion." But whether or not the reasoning relied on had the complete concurrence of the four Justices who made up the majority in Houston $v$. Moore, the doctrine of that case has been so constantly reaffirmed by the Court - most recently in $1962^{85}$ - that it can no longer be doubted. As the Court said in Robbv. Connolly:

Upon the State courts, equally with the courts of the Union, rests the obligation to guard, enforce, and protect every right granted or secured by the Constitution of the United States and the laws made in pursuance

78. Id. at 24.

79. 1 Stat. 73 (1789).

80. 18 U.S. (5 Wheat.) at 26.

81. Houston v. Moore is by no means the only instance of state courts' enforcing federal criminal laws. See Warren, Federal Criminal Laws and the State Coutrts, 38 HaRv. L. REv. 545 (1925).

82. 18 U.S. (5 Wheat.) at $47,76$.

83. 18 U.S. ( 5 Wheat.) at 32 .

84. Ibid.

85. Charles Dowd Box Co. v. Courtney, 368 U.S. 502, 508 n.5 (1962) (referring expressly to pp. $25-27$ of 18 U.S. (5 Wheat.), the heart of the reasoning of Washington, J.). 
thereof, whenever those rights are involved in any suit or proceeding before them. ${ }^{88}$

In the light of these ancient and never discarded propositions, the notion of Tarble's Case that state and federal governments and courts are strangers to each other cannot be justified. In our federal system, the two sovereignties have their distinct powers and limitations. But all the courts of this nation, federal and state, are open to enforce those limitations and aid those powers, in cases that come within their jurisdiction as defined by the power, federal or state, that created them. Federal and state law are inseparable parts of one system of jurisprudence, binding alike on all persons within the boundaries of any given state. ${ }^{87}$ "[T] his theory and practice," said Chief Justice White,

is but an expression of the principles underlying the Constitution and which cause the governments and courts of both the Nation and the several States not to be strange or foreign to each other in the broad sense of the word, but to be all courts of a common country, all within the orbit of their lawful authority being charged with the duty to safeguard and enforce the right of every citizen without reference to the particular exercise of governmental power from which the right may have arisen, if only the authority to enforce such right comes generally within the scope of the jurisdiction conferred by the government creating them. ${ }^{88}$

For a state court, accordingly, to order a federal official to act according to federal law, or to obey valid state law that Congress has not displaced, is no usurpation, nor any assertion that state courts are superior to federal courts or federal officials. It is rather an assertion of the supremacy of law, and especially of federal law. ${ }^{83}$

In fact, it is the supremacy clause itself, so confidently relied on by Ableman v. Booth, Tarble's Case, and various commentators ${ }^{20}$ in opposing statecourt jurisdiction, that conclusively demonstrates the contrary. That clause provides:

This Constitution, and the Laws of the United States which shall be made in Pursuance thereof; and all Treaties made, or which shall be made, under the Authority of the United States, shall be the supreme Law of the Land; and the Judges in every State shall be bound thereby,

86. 111 U.S. 624, 637 (1884). Accord, e.g., Irvin v. Dowd, 359 U.S. 394, 404 (1959); United States v. Bank of New York \& Trust Co., 296 U.S. 463, 479 (1936); Galveston, H. \& S.A. R.R. v. Wallace, 223 U.S. 481, 490-91 (1912). Robb, it should be noted, expressly distinguished Ableman v. Booth and Tarble's Case. But the Court's conservatism in thus declining to cast doubt upon its own precedents must not be allowed to obscure the fact that the governing principle of Robb squarely rejects the assumptions on which Ableman and Tarble rest.

87. Claflin v. Houseman, 93 U.S. 130, 136-37 (1877).

88. Minneapolis \& St. L.R.R. v. Bombolis, 241 U.S. 211, 222 (1916).

89. Cf. Fay v. Noia, 372 U.S. 391, 403 n.11 (1963).

90. See Comment, Power of a State Court to Enjoin National Labor Relations Board Officials, 36 Mrcm. L. Rev. 1344 (1938); Warren, Federal and State Court Interference, 43 HaRv. L. Rev. 345, 348-58 (1930); Bishop, The Jurrisdiction of State and Federal Courts Over Federal Officers, 9 Colux. L. Rev. 397, 407 (1909). 
any Thing in the Constitution or Laws of any State to the Contrary notwithstanding. ${ }^{91}$

The clause, significantly, is directly addressed to state judges: they are bound by the Constitution, and must enforce it. They are also bound by valid federal law, and if in a suit against an official of the federal government an authority validly conferred by that Government is asserted as a defense, they must honor it. But the supremacy clause demands, not that any federal law be automatically enforced by state judges, until invalidated by a federal court, as Tarble's Case suggests, but that state judges apply federal laws "made in Pursuance" of the Constitution. As Mr. Chief Justice Marshall said in Marbury v. Madison, "not the laws of the United States, generally, but those only which shall be made in pursuance of the constitution," are the supreme law of the land. ${ }^{83}$ And, since it "is emphatically the province and duty of the judicial department to say what the law is," 94 it follows that state courts are not only permitted, but obligated, to examine the validity of federal authority asserted in cases before them. Nor can reverence for official authority bar state court examination of federal agents' actions. For in our system of government no official, high or low, is solutus legibus, like the Roman emperors. ${ }^{95}$ All are under the law and subject to its paramount obligation.

How, then, can state court jurisdiction to control federal officials be doubted? If it is feared that injunctions are too drastic an interference with the workings of the federal government, why is not the doctrine of sovereign immunity, which bars relief against the Government and, in circumstances in which the relief prayed will seriously interfere with governmental functions, against its officers, a sufficient protection? If it is feared that state courts will, perhaps deliberately, refuse to honor the defense of sovereign immunity and other federal law defenses, the answer is that Congress has provided a whole arsenal of protective weapons against such state action. Apart from appellate review in the Supreme Court, which has been criticized as too slow, every federal official sued civilly or criminally in a state court on account of an official act has the right of removal to a federal forum, ${ }^{96}$ and if he is imprisoned by state authorities, the federal courts will release him on habeas corpus if the case is of urgent federal concern. ${ }^{97}$ Finally, Congress can always make federal court jurisdiction exclusive by special statutory provision, thus cutting off state

91. U.S. ConsT. art. VI, $\$ 2$.

92. 5 U.S. (1 Cranch) 137, 180 (1803).

93. Compare McCulloch v. Maryland, 17 U.S. (4 Wheat.) 316, 436 (1819) (Marshall, C.J.): "The States have no power, by taxation or otherwise, to retard, impede, burden, or in any manner control, the operations of the constitutional laws enacted by Congress." (Emphasis supplied.)

94. Marbury v. Madison, 5 U.S. (1 Cranch) 137, 177 (1803).

95. See, e.g., Marbury v. Madison, 5 U.S. (1 Cranch) 137, 170-71 (1803) (Secretary of State).

96. 28 U.S.C. $\$ 1442$ (1958).

97. 28 U.S.C. $\$ 2241$ (c) (3) (1958). 
court power to proceed even against those federal officials who do not want a federal forum and would not use their right of removal. ${ }^{98}$

There remains the objection that in spite of the technical and doctrinal plausibility of state court jurisdiction to enjoin federal officials, ${ }^{99}$ those officials are just too important to be left to the mercy of state judges. This appears to have been the feeling of the federal courts about state court obstruction of the Fugitive Slave Acts. It is not hard to think of modern analogues. The feeling is very likely behind cases like Alabama ex rel. Gallion v. Rogers. ${ }^{100}$ The Attorney General of the United States applied to the United States District Court for the Middle District of Alabama for an order permitting him, by authority of Title III of the Civil Rights Act of $1960,{ }^{101}$ to inspect voting records in the possession of the Board of Registrars of Montgomery County, Alabama. The defendant Board moved to dismiss and counterclaimed for an injunction against the enforcement of Title III, on the ground of the unconstitutionality of that statute. In the meantime, the Attorney General of Alabama sued the Attorney General of the United States in a state court, and obtained from that court a temporary injunction against the enforcement of the federal statute, also on the ground of unconstitutionality. The federal Attorney General then removed the state court suit to the Middle District of Alabama, where his own case was pending. He moved the district court to dissolve the injunction and dismiss the state court suit. The district court granted the motion, and the court of appeals affirmed on the lower court's opinion.

A number of sufficient grounds can be thought of for this decision. The best is that Title III of the Civil Rights Act of 1960 is clearly constitutional, so

98. It could, for example, be provided that the jurisdiction of three-judge district courts to enjoin the enforcement of federal statutes on the ground of unconstitutionality, 28 U.S.C. $\$ 22 \$ 2$ (1958), shall be exclusive of state courts. Arguably, Congress, in creating a special forum, intended - though it did not, as is customary, say so - that the three-judge courts have exclusive jurisdiction (a case, in other words, of implied exclusivity). I do not find that such an argument has ever been made. In any event, it would explain only cases decided since 1937 , when $\$ 2282$ was enacted, and it would also require that state courts be held to have lost jurisdiction to enjoin the enforcement of state statutes on the ground of repugnance to the federal Constitution (an unheard-of proposition), since Congress has provided special three-judge district courts for that class of cases as well, 28 U.S.C. $\$ 2281$ (1958).

99. In addition to the authorities already cited, it is worth noting that Professor Moore believes that "justice and sound federalism" support the jurisdiction as a general proposition. 1 Mloore, Federal Practice ff 0.6[5], at 251 (2d ed. 1961). Compare Note, Limitations on State Judicial Interference with Federal Activities, 51 ColuM. L. REv. S4 (1951); Note, 55 HARv. L. KEv. 674 (1942), each of which argues that there should be jurisdiction, or not, according as each particular case affects federal interests - in other words, that jurisdiction should depend upon a particularistic case-by-case analysis. That kind of solution may be academically satisfying, but questions of power and jurisdiction deserve something closer to bright-line answers.

100. 187 F. Supp. 848 (M.D. Ala. 1960), aff'd per curiam sub nom. Dinkens v. Attorney General, 285 F.2d 430 (5th Cir. 1961), cert. denied, 366 U.S. 913 (1961).

101. 74 Stat. 86 (1960), 42 U.S.C. $\$ 1974$ (Supp. IV, 1963). 
that the state court injunction is simply erroneous on the merits. Furthermore, the state court suit was a clear attempt on the part of the state voting officials to evade the federal forum already chosen by the plaintiff federal Attorney General. Those officials' opportunity to defend the federal court suit was a fully adequate one for assertion of their constitutional claims. But the decision went beyond these grounds. It added that the state court lacked jurisdiction because its injunction was "in violation of the basic legal principle that state courts are without jurisdiction to review the discretion or enjoin the acts of federal officers." 102 Tarble's Case and Keely v. Sanders were cited for this sweeping proposition. This formulation has a new element, it will be observed; it refers to state courts' inability "to review the discretion . . . of federal officers." 103 If the court meant only that state courts may not say that the Attorney General ought to have asked to see the votings records of one county rather than another, it was surely right. But then, federal courts could not do that either. If it meant that the Attorney General had "discretion" to gain access to the voting records even if the statute he invoked were unconstitutional, its conclusion must be questioned. The context indicates that the latter meaning was intended.

Alabama ex rel. Gallion $v$. Rogers has been followed in two later cases. ${ }^{104}$ In one of these, ${ }^{105}$ the Court of Appeals for the Fifth Circuit cited a new authority alleged to preclude state court injunction jurisdiction - Bowles $v$. Willingham. ${ }^{100}$ But this case held simply that Congress could give the federal courts, by express enactment, exclusive jurisdiction of certain cases arising under the Emergency Price Control Act of 1942,107 and that Congress had further authorized federal courts, as an exception to the general prohibition of federal court injunctions against state court proceedings, ${ }^{108}$ to protect this exclusivity by injunction. The precise holding of Bowles was that a federal district court could, and should, enjoin a state court suit itself seeking to en-

102. 187 F. Supp. at 852.

103. The court cited Rogers v. Calumet Nat'l Bank, 358 U.S. 331 (1959) (per curiam), a one page opinion, rendered without argument, in which the Supreme Court did indeed say that "a state court is without power to review the discretion exercised by the Attorney General of the United States under federal law." The case involved the Attorney General's actions as Alien Property Custodian. The meaning of this holding, however, is quite different from the construction put upon it by the District Court in Alabama ex rel. Gallion v. Rogers, as is shown by the Supreme Court's citation of Silesian-American Corp. v. Markham, 156 F.2d 793, 796 (2d Cir. 1946), aff'd, 332 U.S. 469 (1947), in which it was held that Congress had delegated to the President, and the President to the Alien Property Custodian, absolute power, unreviewable by the courts, to choose what alien property to seize, and that these delegations were constitutional. Federal as well as state courts are thus covered by the principle embodied in Calumet Nat'l Bank, sipra.

104. Kennedy v. Bruce, 298 F.2d 860 (5th Cir. 1962); Alabama ext rel. Patterson v. Jones, 189 F. Supp. 61 (M.D. Ala. 1960).

105. Kennedy v. Bruce, supra note 104.

106. 321 U.S. 503, 511-12 (1944).

107. 56 Stat. 23 (1942).

108. See 62 Stat. 968 (1948), 28 U.S.C. \& 2283 (1958). 
join the Administrator of the Office of Price Administration from issuing certain rent orders under the Emergency Price Control Act. The clear assumption of the case is that but for the special protective federal statutes around which the opinion is built, the state court would have had general jurisdiction of the injunction suit.

\section{ConClusion}

At the heart both of the cases denying injunction jurisdiction and of Tarble's Case and Ableman is the notion that since federal law is supreme over state law, the state courts are therefore incompetent to make a decision based on federal law. Since the supremacy clause forbids the state legislatures to make laws on matters which the federal government has legitimately undertaken to control, it is reasoned that the principles of dual sovereignty would also forbid state courts from hailing federal officers before them and giving them explicit directions under the guise of interpreting federal law. The basic assumption of this line of reasoning, that a state court may apply only state law, is, as we have seen, false. State courts are not only competent to apply federal law, but in many instances are the only courts available in which federal law can be enforced. The remaining argument, that for reasons of comity state courts ought to leave the governing of federal officers to the federal courts, ignores the already extensive jurisdiction of state courts over federal officers, and the unique position of the state courts as the only courts of general jurisdiction in the federal system.

It might be suggested that the existing precedents can be rationalized on the theory that state courts have "law" jurisdiction over federal officials (replevin, damages), but not "equity" jurisdiction (injunctions, mandamus). ${ }^{109}$ Judgments at law, the argument would run, are less of an interference with the functioning of the federal government. Habeas corpus, involving as it does a particularly striking form of interference, would, in this view, be classified with the "equity" cases. Apart from the fact that this suggested rationale exalts form over substance - a replevin judgment, for example, may in practice be the equivalent of an injunction - it fails to give full application to the underlying principle that state courts as well as federal have a duty to enforce the limitations that federal law imposes on federal officials. The law-equity distinction, furthermore, has the additional weakness that it fails to explain state court criminal jurisdiction over federal officers - a jurisdiction potentially productive of the most drastic interference of all. The impact of this criminal jurisdiction has not, perhaps, been great, since federal officers have the protection of removal ${ }^{110}$ and federal habeas corpus. ${ }^{111}$ But its undoubted existence is inconsistent with the suggested law-equity distinction.

109. Mandamus is not, of course, historically an equitable writ. It is a prerogative writ issuable out of the Court of King's Bench, a law court. But it may be classified as equitable for present purposes because its effect is similar to that of an injunction.

110. Tennessee v. Davis, 100 U.S. 257 (1880).

111. In re Neagle, 135 U.S. 1 (1889). 
Thus, reason and the basic principles of our federal system compel the conclusion that state courts have power to issue injunctions against federal officials. The force of the foregoing reasoning would also lead to the conclusion that state courts may issue habeas corpus and mandamus against those offcials. I, for one, would cheerfully accept such a conclusion, as it would wipe from the books a body of demonstrably unsound doctrine. In any event, the mandamus area is hardly of present importance, since that writ can be supplanted entirely by the mandatory injunction. As for any ills thought to derive from state court habeas corpus review of federal detention, Congress can fashion whatever remedy is necessary. In advocating the existence of such jurisdiction, however, I do not wish to be understood as countenancing its indiscriminate use or abuse. Considerations of comity and of deference to federal policy will often dictate restraint on the part of the state courts. And the Supreme Court, which will of course sit in judgment over the state courts' exercise of their jurisdiction over federal officials, will be able to develop decisional rules particularizing the instances in which, as a matter of comity, state courts should abstain.

As long as federal officials have their present broad right of removal, adoption of the position advocated in this article would have only a limited practical effect. It would probably not increase the instances in which state courts actually grant relief against federal officials. It would, however, have the derivative effect of opening the federal courts to many plaintiffs who are now without a remedy. This effect would in itself be of great importance, since it would increase the extent to which federal rights are protected against the federal bureaucracy. Of course, the existing broad right of removal is not necessarily permanent. Congress gave it only in 1948, and Congress can take it away.

In a commendable desire to enforce federal law, and under provocation from state courts whose respect for federal law is not what it should be, some federal courts have from time to time succumbed to temptation and announced that state courts lack power to issue injunctions against federal officials. In fairness, the federal courts cannot be censured too severely. State courts who issue injunctions as freely as the Alabama county court did in the Gallion case are only bringing federal retaliation on themselves. They are as much, if not more, at fault as federal courts who sweepingly deny state jurisdiction. But one doubts that the vindication of federal policy requires distortion of fundamental federalist principles. After all, means are important as well as ends, and the day may come again when the state courts are called upon to enforce the Constitution in cases where the federal courts are powerless. In the long run, it will be the part of wisdom to heed the words of the first Justice Harlan in Minnesota v. Brundage:

It cannot be assumed that the state court will hesitate to enforce any right secured ... by [the federal Constitution] ... . ; for upon them equally with the courts of the Union rests the duty to maintain the supreme law of the land.112

112. 180 U.S. 499,503 (1901). 


\section{THE YALE LAW JOURNAL}

JoHN GRIFFTrHS Owen J. Sloane Allan A. Tutrle Michael A. VARET Note \& Comment Editors

Jonatenan A. Ater RICHARD J. BRAEAKER DenNIS K. BRoMrLEY E. Edward Bruce Michael A. Brush Robert A. Carter Anthony A. Dean W. LeE H. DunhaMr Roger D. FeLDMraN Gregory C. GLYNN

JAMES T. B. TRIPP Business Manager

\section{Charles M. Nathan Editor-in-Chief}

\section{MarTIN E. LowY Managing Editor} \\ JANRES S. GoRDON \\ Micharl F. Halloran \\ C. StepHen Howard \\ Martin D. KRaLl \\ Stron Lazarus, III \\ Betsy LeviN \\ Camieron F. MacRae \\ Rod MCMAHAN \\ LEONARD M. MaRKS
}

Daniel Marcus

Topics Editor

Charles Donahue, JR.

SHERwin M. Goldmin

Article \& Book

Revieze Editors

\author{
Anita S. Martin \\ Barbara H. PaUl \\ Edward A. Perell \\ David A. RaHAS \\ LEoNarD M. Ross \\ FRED E. ScharF \\ Benno C. Scharmt, Jr. \\ LARRY G. STMON \\ WILLARD B. TAYLOR \\ Peter L. Zimroth
}

\section{Bezra Seidenbaum}

Business Secretary

We wish to express our thanks and appreciation to the outgoing board of the Journal.

\section{CONTRIBUTORS TO THIS ISSUE}

Edgar S. CAHn. B.A. 1956, Swarthmore College; M.A. 1957, Yale University; Ph.D. 1960, Yale University and Pembroke College, Cambridge University; LI.B. 1963, Yale University.

Jean C. Cann. B.A. 1957, Swarthmore College; LL.B. 1961, Yale University and Newnham College, Cambridge University.

LaURent B. Frantz. A.B. 1932; LL.B. 1935, University of Tennessee; LL.M. 1950, Duke University; B.L.S. 1951, University of California, Berkeley.

Rrcerard S. Arnold. B.A. 1957, Yale University; LL.B. 1960, Harvard University.

Frederick C. Barghoorn. B.A. 1934, Amherst College; A.M. 1935; Ph.D. 1941, Harvard University.

Gerlud M. Caplan. B.A. 1959; M.A. 1960; J.D. 1963, Northwestern University.

Alan Schwartz. B.S. 1961, Bates College; LL.B. 1964, Yale University. 